\title{
Developed lighting technology for Smart Cities
}

\author{
$1^{\text {st }}$ Michal Cehlár ${ }^{1}, 2^{\text {nd }}$ Dušan Kudelas ${ }^{2}$ \\ \{michal.cehlar@tuke.sk ${ }^{1}$,dusan.kudelas@tuke.sk\} \\ Ústav zemských zdrojov, Fakulta BERG TU v Košiciach, Letná 9, 04200 Košice $^{1}$, Ústav zemských \\ zdrojov FBERG TU v Košiciach, Park Komenského 19, 04200 Košice ${ }^{2}$
}

\begin{abstract}
It is estimated that to year 2050, it will almost $70 \%$ people live in urban areas. Cities need go through evolution and change in the Smart Cities. They are energy efficient, save resources, produce low emissions and provide citizens a better quality of life. Also in Slovakia is formed public opinion and idea about what Smart City means in practice. It is a complex innovation in all spheres of life of the people and infrastructure of the city, using new materials and the latest information and communication technologies. The aim of presented paper is show chosen developed technologies at Institute of Earth sources, which can be used for Smart cities.The abstract needs to summarize the content of the paper.
\end{abstract}

Keywords: solar wind lamp, windbelt, autonomous lighting, public lighting

\section{Introduction}

Residents expect from their city real innovation, not only small improvements. They want to single points of contact and access to information at the level of the 21 st century, without unnecessary forms, stamps and office visit. They want to know if their residence is not on the maps of crime or flood maps in the critical region. They want to keep track of traffic conditions and parking [10].

Together with the concept of Smart City we gets another term - Placemaking. That deals with life and spaces between objects. In the foreground are the people and their needs. People who are from the city, from her living space expect some elementary functionality. Require decent infrastructure and smooth transport, sufficient amenities and services, lots of greenery, low emissions and a safe environment for themselves and their children. Each group of people, each sector (for example, entrepreneurs in trade and services, cultural, community and nonprofit organizations), however, has specific requirements [10].

Buildings are responsible for 36-40 \% of global energy consumption. Therefore, the concept of Smart City often associated with energy savings, finding her alternative sources and reducing carbon footprint. Thanks to smart energy solutions and the concept has been reached $5 \%$ of the potential savings in smart cities. One of the solutions is a smart connected infrastructure, what is able to increase its value tenfold. For example, data from energy metering and lighting (public and private) that is collected and evaluated, contribute to better energy balance [10].

The concept of "smart cities" is characterized by the interconnection of information and communication technologies (ICT) with already extensive and costly critical infrastructure such as energy networks, transport networks, waste management, health, etc., and thanks to precise monitoring and control system allows increased efficiency and the amount of savings. In addition to the deployment of intelligent sensors and universal access to smart phones (and their 
complementarity) has a 'smart cities' potential to empower communities and realize significant benefits in terms of efficiency, creativity, and even the participation of local citizens in the democratic process. Therefore, the concept of smart cities naturally becomes an interesting opportunity for the city government, and often so there is a rapid adoption of "smart" solution. However, uncontrolled, rapid development of smart initiatives and technology complexity for integrating existing infrastructure with ICT opens the door to potential cyber threats, which in turn can have a negative impact on the community [6].

\section{Mobility and transportation in Smart City}

Mobility and transportation are an essential part of the urban infrastructure. Smart city should be easily accessible to visitors and its inhabitants. Travel through the city should be smooth and comfortable but also environmentally friendly. The aim is to provide a versatile, efficient, safe and comfortable transportation systems that are connected to the infrastructure of information and communication technologies and open data [9].

Within the concept of Smart Cities are the trends in transport as follows [9]:

- Operation monitoring system

- Sharing of transport

- Intelligent traffic management

- Intelligent traffic lights

- Intelligent traffic information

- Sharing experiences of citizens with transportation

- Intelligent parking spaces

- $\quad$ Bike Sharing

- Electric vehicles

- Optimization and popularization of public transport

In most large cities in the Czech Republic and Slovakia they are similar to problems of transport such as in Brno [9]:

- Incomplete main ring road

- The lack of a complete system of superior communications

- State Railway Junction

- Unfinished part of the city sewer, unresolved flood protection

- Collision of parking and traffic (mainly pedestrian)

- Stagnation in the development of infrastructure for rail transportation

- Preference of individual car transport to the detriment of pedestrians, cyclists and public transport

- $\quad$ Lack of bicycle paths and bicycle lanes

- Lack of parking and garage space in the city center and housing estates

- The lack of car parks

- Lack of public transport attractiveness 


\section{Proposed public lighting}

Public lighting is not only part of the local color of each town or village, but is also an essential part of the transport system. A considerable part of the expenses of municipal government. With the growth of prices for consumed energy by lighting system grows and requirement of self-sufficiency in the acquisition. Currently it is taking place in the whole territory of Slovakia reconstruction of public lighting, which is addressed by implementing European standards. There are several types of street lamps, which on its operation using renewable energy sources. Our proposal is an intelligent LED solar lamp of public lighting with wind aggregate. In general, the lighting system consists of a set of features and technical means to ensure the correct lighting such as lamps, luminaires, poles with electric equipment, power cables, switchgear, etc.

Intelligent LED Street lighting that combines a camera system, wireless networks and sensors. In addition to significant energy savings and energy supply management, contributes to a better awareness of the city traffic conditions and parking. While it is increasing safety on the streets. Linkable also for applications in smartphones, with street lamps serve as a "beacon" for navigation of tourists. They can also be transmitters of marketing messages and important announcements of the city management. Ecologic production and moderate energy consumption is only one side of the coin. It is important to be able to predict the state of freedom of the regulatory power and the unused energy office building over the weekend to divert to residential block. Smart City vision is to achieve complete energy self-sufficiency city, which will not produce and "export" waste. All these by respecting local conditions and individual character of the city [10].

Public lighting in Slovakia is made up of several types of lighting columns with the most commonly used as concrete and steel. Lights are placed on these types using the boom arm with different angles or directly [1]. As the lamps are currently used incandescent, fluorescent lamps, compact fluorescent lamps, LEDs and other species.

As a source of electricity, we propose two alternatives: Savonius rotor, respectively technology "windbelt". Savonius rotor belongs to the device with a vertical axis of rotation VAWT. Rotor blades with a vertical axis of rotation are long and rounded at both ends fixed. Their main advantage over systems with the horizontal axis of rotation, it is not necessary to capture the wind flow in different directions.

Savonius rotor is low-speed wind machine. It is a type of vertical-axial wind turbine. It uses the pressure difference in the flow of air and the round hollow semicircular scoop which, when viewed from above has the form of the letter "S". The efficiency of the device is moved only by the $\eta=0.2$, but is structurally simple with good start-up characteristics even at low speeds of wind and is characterized by a high starting torque [2].

Currently, are widespread construction with two or three wings, because the higher number is decreasing effectiveness. Semicircular blades are curved and mounted in the middle of the opposite. The direction of rotation can be so right and to the left. The speed of the rotor depends on its diameter, the load and the wind speed. Our proposed road lamp with wind aggregate consists of a steel mast with a height of $8 \mathrm{~m}$ and a length of boom $1.5 \mathrm{~m}$.

Rotor area is $4 \mathrm{~m} 2$. It is essential that the blades are made of a light material, it is proposed to construct the plastic with addition of glass fiber. The rotor is mounted through the cage surround of the shaft that transmits torque to the transmission. Transmission with gears is used for converting the input torque for the rotational movement. It allows us to set up several gears. Transfers energy to the flywheel, which converts mechanical energy from the rotor into electrical energy which produces a direct current. In order to ensure business continuity in times 
of operation lamp it is necessary to provide switching between battery and distribution networks which support element having a switching function. This element battery charged, it automatically connects the lamp to the network which distributes electricity. The battery is charged continuously for 24 hours. The final appearance of such a lamp in 3D can be seen in Fig. 1.

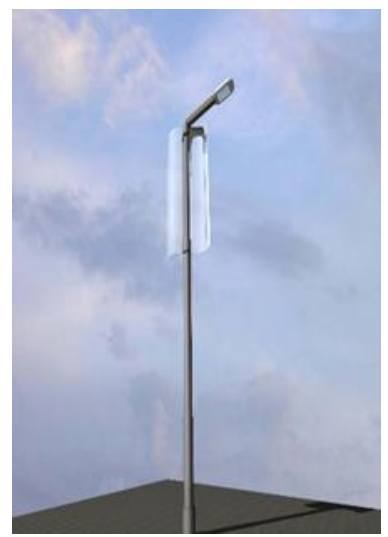

Fig. 1. View of a wind accumulation lamp

Savonius rotor does not cover the overall demand for electricity and the lighting should be equipped with PV panel.

Another alternative is to use technology of windbelt. The aim of our research is the applicability of technologies to generate electricity from the air stream as part of an autonomous light source. Lack of equipment for the use of low potential winds prompted the present investigation, one of the objectives is to optimize technology for air flow rate is low at the same time the production of sufficient power for lighting and meet the safety parameters.

Principle of windbelt is follows: tensioned membrane (tape), under the influence of wind flow vibrates, see Fig.2. Flapping causes movements of the permanent magnet, which is attached to the membrane. Oscillating magnet moving between these coils induces a voltage coils. Since the Windbelt a number of other "flutter" wind harvester devices have been designed, but like the Windbelt almost all have efficiencies below turbine machines. But the main advantage is that can produce electricity at wind speed lower as conventional wind devices. 1-metre version that could be used to power LED lights can generate $10 \mathrm{~W}$ average. 


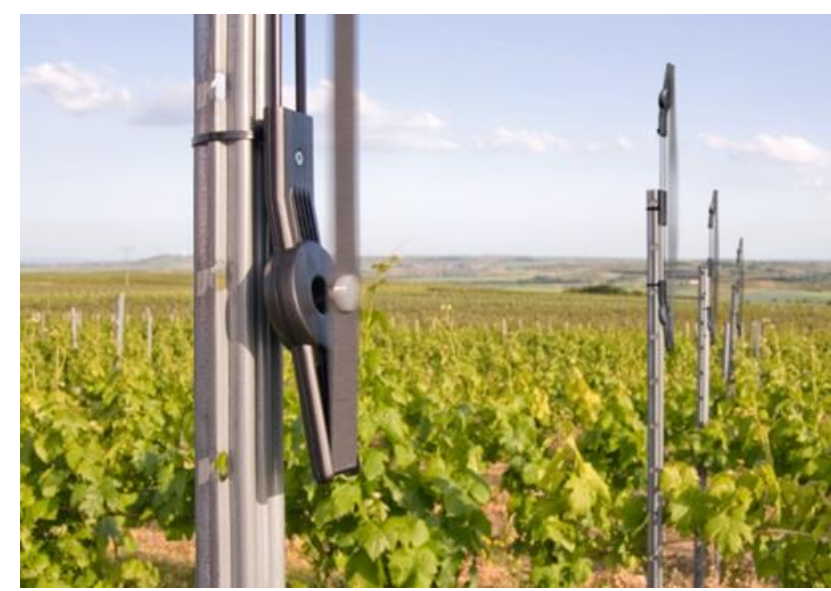

Fig. 2. Windbelt technology [8]

At present, it remains the most effective way of using solar energy use so-called photovoltaic panels, see Fig.3. Scientists are already quite a long period considering the idea, as one would use photovoltaic panels in practice even more effective [7].

Innovative photovoltaic panels are the first fully transparent, which is considered a key point of this innovation. Upgrading these panels is the fact that during the day the sun's rays impinge on transparent photovoltaic panel that performs two functions. The first function is that the space required by the sun's rays are released and the second function is that some of these rays are directed to the perimeter of the panel. The great advantage of this innovation is also that all the so-called glass building to become producers of their own electricity, so would also save costs and reduce the pressure on the ecology. In the past were a number of attempts to package glass building by photovoltaic panels, however, has a problem in that the panels change the visibility of these windows while reducing the amount of natural light in a given area, which was simply undesirable. The problem is, as with a number of developed technologies low efficiency, yet [4].

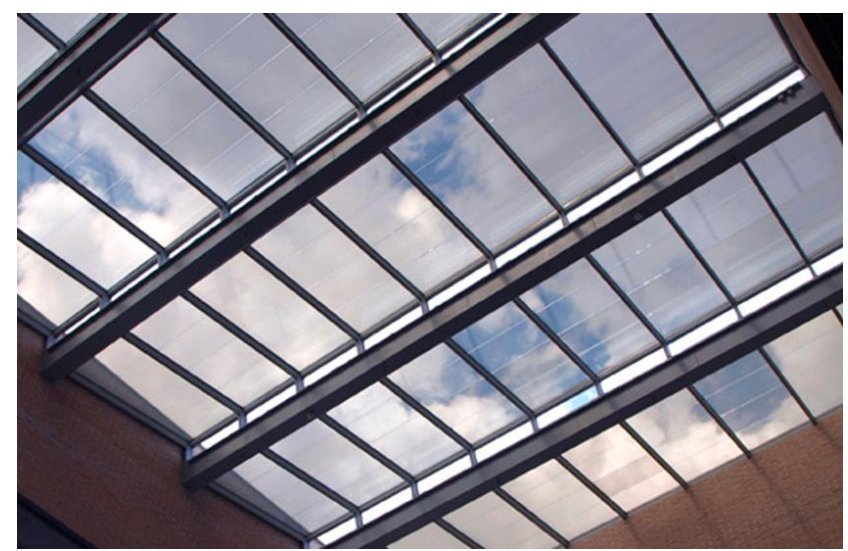

Fig. 3. Innovative transparent PV panels [4]. 


\section{Conclusion}

Use of renewable sources for smart cities is essential, but useful technologies are particularly photovoltaic panels and wind energy. In implementing the concept of Smart Cities, however it must also have in mind, not only trendy and marketing issues, but also consider the potential risks, for example cooling of server stations for managing the infrastructure and with the possible increase of energy consumption, cyber threats and possible energy outages. Therefore, autonomous lighting sources and new technology could be beneficial solution. While these risks are not solved, but these technologies do not contribute to their formation.

\section{References}

[1] Verejné osvetlenie [online]. 2005.[cit. 2012-04-26]. Dostupné z: http://www.verejneosvetlenie.sk/master/ Goinggreendiy.com [online]. 2009 [cit. 2010-0401]. How To Build A Solar Panel. Dostupné z WWW: <http://goinggreendiy.com/windturbine-informatio/>.

[2] Schulz, Heinz. Savoniův rotor - návod na stavbu. Ostrava : HEL, 2005. 80 s. ISBN 808-616$72-67$.

[3] Rybár, R., Kudelas, D., Rybárová, J., Beer, M.: Parallel Manifold Header on Foam Material Basis for vacuum Tube Solar Collectors / Radim Rybár ... [et al.] - 2013. In: Advance Science Letters. Vol. 19, no. 2(2013), p. 591-594. - ISSN 1936-6612

[4] Radimak, E.: Priehl'adné fotovoltaické panely ako nový zdroj energie. http://www.setri.sk/priehladne-fotovoltaicke-panely-ako-novy-zdroj-energie/

[5] Lom, M., Přibyl, O.: Smart Cities aneb města budoucnosti II. http://elektro.tzbinfo.cz/informacni-a-telekomunikacni-technologie/14209-smart-cities-aneb-mestabudoucnosti-ii

[6] Tobiáš, L.: Smart cities a kybernetická bezpečnost. SCmagazín 02/16. http://www.scmagazine.cz/casopis/02-16/smart-cities-a-kybernetickabezpecnost?locale $=\mathrm{cs}$

[7] http://www.smart-magazine.com/en/tomorrows-sustainable-city-smart-electric-drive/

[8] http://www.p-stadtkultur.de/made-in-darmstadt-wolt

[9] https://cs.wikipedia.org/wiki/Smart_City\#Chytr.C3.A1_doprava_.28Smart_Mobility.29

[10] Digitálna transformácia inteligentné mesto. Atos e-book 